\title{
Naive T Cell-Depleted Hematopoietic Stem Cell Transplantation
}

National Cancer Institute

\section{Source}

National Cancer Institute. Naive T Cell-Depleted Hematopoietic Stem Cell

Transplantation. NCI Thesaurus. Code C154917.

The removal of naive T-cells from the donor's hematopoietic stem cell specimen prior to its transfusion into the recipient. 